\title{
Inheritance of Leaf Shape and Main Vein Color in Caladium ${ }^{1}$
}

\section{Z. Deng and B.K. Harbaugh ${ }^{2}$}

The ornamental value of caladiums (Caladium $\mathrm{x}$ hortulanum Birdsey) depends, to a great extent, on leaf characteristics including shape, color, color pattern, and venation pattern. Broadly, caladium leaves are classified into three shapes: fancy, lance, and strap (Fig. 1). Fancy-leaved caladiums have heart-shaped (triangular- or round-ovate) leaves, with three main veins on each leaf arranged in the form of an inverted letter $Y$. They have a peltate petiole attachment, and the two basal lobes are joined for more than one-fifth of their length and separated by a short, narrow sinus. Strap-leaved caladiums, on the other hand, have narrow linear (or ribbon-like) leaves, with one main vein and no obvious basal lobes. Lance leaves are intermediate between fancy and strap types: leaf blades are broad sagittate to cordate-lanceolate, with basal lobes not obvious or broadly separated by a sinus, if present. Caladium leaf shapes are closely associated with plant growth habit, stress tolerance, tuber yield, etc. Generally, strap- or lance-leaved plants are much shorter in plant height, sprout more leaves from similarly-sized tubers, are more tolerant of sun and low temperatures, and produce smaller tubers than fancy-leaved plants.
Leaf color is another important characteristic in caladium. It is determined by the color of veins (main, secondary and peripheral), interveinal areas, spots, and/or blotches. Leaf colors in many caladium cultivars are extremely diverse and intriguing. In some cultivars, leaf colors and colored areas can be quite variable on the same plant with changes in plant development or environmental conditions. Leaf color variation or instability may be undesirable for commercial production or propagation. However, the leaf main vein color seems to be stable under different environments, on different plants, or at different developmental stages. This stability of color expression in leaf main veins has been useful for cultivar description and identification, besides its ornamental significance.

Caladiums are diploids with $2 \mathrm{n}=2 \mathrm{x}=30$ chromosomes. Information about the inheritance of leaf shape and main vein color has been rather scant in caladium. In recent years, efforts have been made to have a better understanding of the inheritance of these characteristics for improved breeding efficiency. This type of information may also be useful to commercial growers, gardeners or master gardeners who are interested in backyard breeding, or

1. This document is ENH1006, one of a series of the Environmental Horticulture Department, Florida Cooperative Extension Service, Institute of Food and Agricultural Sciences, University of Florida. Original publication date August 2005. Visit the EDIS Web Site at http://edis.ifas.ufl.edu.

2. Z. Deng, assistant professor; B.K. Harbaugh, professor, Gulf Coast Research and Education Center, Cooperative Extension Service, IFAS, University of Florida, Gainesville 32611.

The Institute of Food and Agricultural Sciences (IFAS) is an Equal Opportunity Institution authorized to provide research, educational information and other services only to individuals and institutions that function with non-discrimination with respect to race, creed, color, religion, age, disability, sex, sexual orientation, marital status, national origin, political opinions or affiliations. U.S. Department of Agriculture, Cooperative Extension Service, University of Florida, IFAS, Florida A. \& M. University Cooperative Extension Program, and Boards of County Commissioners Cooperating. Larry Arrington, Dean 
breeding hobbyists, whose efforts contributed once to the development of a number of commercial cultivars, for them to design their breeding plan.

Controlled crosses were made among ten cultivars and two breeding lines; their progeny were analyzed to understand the inheritance of leaf shape and main vein color and to determine if there is a genetic linkage between these two traits. The segregation ratios were also used to determine the genotype of a number of major cultivars that are of significant value as breeding parents in caladium cultivar improvement.

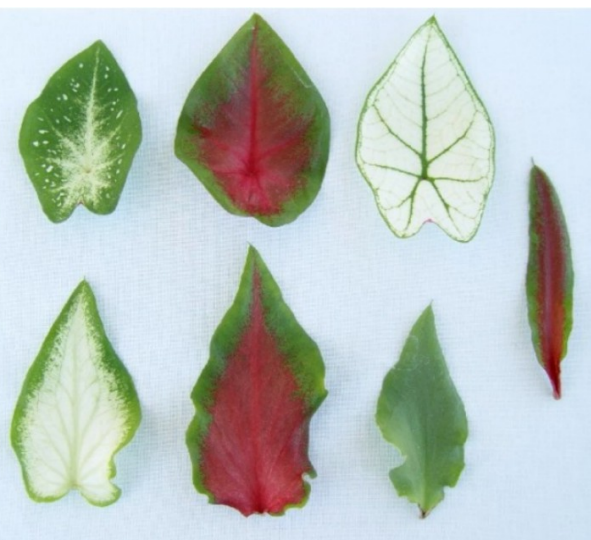

Figure 1. Typical leaf shapes and main vein colors expressed in caladium progeny (seedlings approximately 3 months old). Top row from left to right: fancy leaves (heart-shaped with petioles attached to the back) with white, red, and green main veins; bottom row from left to right: lance leaves with white, red, and green main veins. Rightmost column: strap leaf with red main vein. Credits: UFGCREC

\section{Inheritance of Leaf Main Vein Color}

The main vein of 'Candidum' and 'Candidum Jr.' is green. Progeny from selfing of 'Candidum' and crossing with 'Candidum Jr.' expressed green main veins (Table 2 ), consistent with a previous report (Wilfret, 1983) and indicating the homozygosity status of their vein color. Previously, Wilfret $(1983 ; 1986)$ showed that the green vein color was recessive to both red and white main vein colors. Therefore, 'Candidum' and 'Candidum Jr.' should both contain homozygous recessive alleles for their green vein color.

'Florida Fantasy' expresses red main veins; its genotype was determined by testcrossing with
'Candidum Jr.'. Two types of vein colors, red and green, were observed in the progeny of reciprocal crosses between 'Candidum Jr.' and 'Florida Fantasy', and they segregated in a 1:1 ratio (Table 2), indicating that 'Florida Fantasy' is heterozygous. To confirm this, 'Florida Fantasy' was crossed with another green-veined cultivar, 'White Christmas', and a 1:1 ratio between red- and green-veined progeny was again observed (Table 2).

'Florida Red Ruffles' was tested using both 'Candidum' and 'Candidum Jr'.; their testcross progeny exhibited a 1:1 segregation of red- and green-veined individuals, indicating that 'Florida Red Ruffles' is heterozygous at the locus determining the leaf main vein color.

Three crosses were made to test 'Florida Sweetheart', including reciprocal crosses with 'Candidum Jr.' and a cross with 'Candidum'. The 1:1 ratio between red- and green-veined progeny indicated that 'Florida Sweetheart' is heterozygous as well.

The 1:1 segregation of red and green vein colors in the progeny of the cross between 'Candidum' $x$ 'Red Flash' revealed that 'Red Flash' is heterozygous. This was confirmed by selfing and crossing with 'Florida Fantasy'. Since both parents were heterozygous in these two crosses, a segregation ratio of 3 red: 1 green was expected, and observed (Table 2).

To understand the relationship of white veins over red and green veins, two cultivars ('Aaron' and 'Florida Moonlight') and one breeding line (BR-1) that express white main veins (Table 1) were chosen, and they were selfed or crossed with some of the above-characterized cultivars. Progeny of selfed 'Florida Moonlight' exhibited segregation of white and green main veins in a 3:1 ratio (Table 2), which indicates that 'Florida Moonlight' is heterozygous and that white is dominant to green. 'Florida Moonlight' was then crossed separately to three heterozygous red-veined cultivars ('Florida Fantasy', 'Red Flash', and 'Florida Sweetheart'). Three types of individuals (red, white, and green-veined) were observed in the progeny of these crosses; they segregated in a 2:1:1 ratio (Table 2). This 
segregation suggests that red is dominant over white and green, and white is dominant over green.

When white-veined breeding line BR-1 was crossed with 'Florida Fantasy' (heterozygous red-veined), a similar segregation of vein colors (2 red: 1 white: 1 green) was observed in their progeny (Table 2), which supports that red is dominant over white.

Progeny of reciprocal crosses between 'Aaron' and 'Red Flash' segregated into two main vein colors, red and white, in a 1:1 ratio (Table 2). This segregation again support the above proposed dominance of red over white, and also indicates that 'Aaron' is homozygous white-veined, different from 'Florida Moonlight'.

In summary, the above segregation data supported previous observations (Wilfret, 1983; 1986) that the green main vein phenotype is controlled by a recessive allele, and that the red main vein is dominant over the green main vein. They revealed that four of the major red-veined commercial cultivars are heterozygous, containing both the red and green vein alleles. These data confirmed the dominance of white main veins over green main veins, but revealed a different relationship between red and white main veins. White is not dominant to red, rather red is dominant to white. It seems that caladium has evolved several alleles for the main vein color. The locus determining the main vein color was designated as $V$, with three alleles $V^{r}$, $V^{\mathrm{W}}$, and $V^{\mathrm{g}}$ for red, white, and green main veins, respectively. The dominance order of these alleles is $V^{\mathrm{T}}>V^{\mathrm{W}}>V^{\mathrm{g}}$. Accordingly, the genotype for the main vein color was inferred from the above-mentioned segregation data and shown in Table 2. 'Candidum' and 'Candidum Jr.' have the $V^{g} V^{g}$ genotype; 'Florida Fantasy', 'Florida Red Ruffles', 'Florida

Sweetheart', and 'Red Flash' share the $V^{r} V^{g}$ genotype. The genotype of 'Aaron' for main vein color is $V^{\mathrm{w}} V^{\mathrm{w}}$, while that of 'Florida Moonlight' and BR-1 is $V^{\mathrm{W}} V^{\mathrm{g}}$.

\section{Inheritance of Leaf Shapes}

Among the thirty-eight crosses, sixteen were fancy $x$ fancy, seven fancy $x$ lance, thirteen lance $x$ fancy, and two lance $x$ lance, respectively. All progeny of fancy x fancy crosses exhibited fancy leaves. Two leaf types (fancy and lance) were observed in the progeny of each of the fancy $x$ lance crosses; their segregation ratio in each population fit 1:1. In 10 of the 13 lance $x$ fancy crosses, the segregation between fancy and lance leaf types fit a ratio of 1:1. However, the segregation in the progeny of three of the crosses was skewed toward more fancy leaf type individuals. This skewedness was most obvious in the cross between 'Florida Red Ruffles' x 'Candidum Jr.'. The cause(s) of this skewed segregation remains to be elucidated. The segregation of three leaf types in the progeny of two lance $\mathrm{x}$ lance crosses fit well to a ratio of 1 fancy: 2 lance: 1 strap.

The above segregation data from four types of crosses indicate that the three leaf shapes in caladium are controlled by two co-dominant alleles at one locus, which supports a previous report (Wilfret, 1986). The two alleles have been named $F$ and $f$, for fancy and strap leaves, respectively. Therefore, the genotype of fancy-, lance-, and strap-leaved caladiums would be $F F, F f$, and $f f$, respectively. The skewedness of leaf shape segregation in some of the crosses indicates that other factors might contribute to the development of leaf shapes.

\section{Independent Inheritance Between Leaf Shape and Main Vein Color}

Both leaf shape and main vein color segregated in the progeny of sixteen crosses. Five patterns of segregation were observed (Table 3). Four types of individuals (fancy red, fancy white, lance red, and lance white) appeared in the progeny of reciprocal crosses of 'Aaron' and 'Florida Sweetheart' in a ratio of 1:1:1:1. This ratio was also observed in another four crosses ('Florida Sweetheart' x 'White Christmas', 'White Christmas' x 'Florida Sweetheart', 'Florida Irish Lace' x 'Florida Fantasy', 'Candidum' x 'Florida Sweetheart') among four different types of individuals (fancy red, fancy green, lance red, and lance green). In three crosses ('Red Flash' x 'Florida Sweetheart', 'Red Flash' x 'Florida Sweetheart', and 'Florida Red Ruffles' x 'Florida Fantasy'), these four types of progeny segregated in a 3:1:3:1 ratio. The progeny of five crosses ('Florida Red Ruffles' x 'Florida 
Moonlight', 'Florida Red Ruffles' x BR-1, BR-1 x

'Florida Red Ruffles', BR-1 x 'Florida Sweetheart', 'Florida Sweetheart' x 'Florida Moonlight') showed six types of individuals, fancy red, white, and green, and lance red, white, and green, in a ratio of $2: 1: 1: 2: 1: 1$, respectively. Six types of progeny (fancy red and green, lance red and green, and strap red and green) were observed in two crosses ('Florida Irish Lace' x BR-2, 'Florida Irish Lace' x 'Florida Red Ruffles'), in a ratio of $1: 1: 2: 2: 1: 1$. Contingency $x^{2}$ tests indicated that the two leaf traits assorted independently.

\section{Literature Cited}

Wilfret, G.J. 1983. Inheritance of vein color in caladium leaves. HortScience 18:610.

Wilfret, G.J. 1986. Inheritance of leaf shape and color patterns in Caladium (Araceae). HortScience 21:750.

Wilfret, G.J. 1993. Caladium, p. 239-247. In: A. de Hertogh and M. le Nard (eds.). The physiology of flower bulbs. Elsevier, New York, N.Y. 
Table 1. Phenotype and genotype (inferred) of ten commercial caladium cultivars and two breeding lines that were used as parents.

\begin{tabular}{|c|c|c|c|c|c|}
\hline \multirow[b]{2}{*}{$\begin{array}{l}\text { Cultivar/ } \\
\text { breeding line }\end{array}$} & \multirow[b]{2}{*}{ Parents } & \multicolumn{2}{|c|}{ Phenotype } & \multicolumn{2}{|c|}{ Genotype } \\
\hline & & $\begin{array}{c}\begin{array}{c}\text { Leaf } \\
\text { shape }\end{array} \\
\end{array}$ & $\begin{array}{c}\text { Main vein } \\
\text { color }\end{array}$ & $\begin{array}{l}\text { Leaf } \\
\text { shape }\end{array}$ & $\begin{array}{c}\text { Main vein } \\
\text { color }\end{array}$ \\
\hline Aaron & Unknown & Fancy & White & $F F$ & $V^{N} V^{N}$ \\
\hline BR-1 & Aaron $x$ Candidum Jr. & Fancy & White & $F F$ & $V^{N} V^{g}$ \\
\hline BR-2 & White Ruffles $x$ Sweetheart & Lance & Red & $F f$ & $V v^{\rho}$ \\
\hline Candidum & Unknown & Fancy & Green & $F F$ & $V^{\rho} V^{\rho}$ \\
\hline Candidum Jr. & Unknown & Fancy & Green & $F F$ & $V^{\rho} V^{\rho}$ \\
\hline Fantasy & Candidum Jr. x Red Frill & Fancy & Red & $F F$ & $V V^{g}$ \\
\hline Irish Lace & $\begin{array}{l}\text { (Candidum Jr. } \times \text { Red Frill) x } \\
\text { (Candidum Jr. x Red Frill) }\end{array}$ & Lance & Green & $F f$ & $V^{\rho} V^{\rho}$ \\
\hline Moonlight & Aaron x Candidum Jr. & Fancy & White & $F F$ & $V^{N} V^{g}$ \\
\hline Red Ruffles & (Red Frill $\times$ Candidum Jr.) $\times$ Red Frill & Lance & Red & $F f$ & $V V^{\rho}$ \\
\hline Sweetheart & Candidum Jr. x Red Frill & Lance & Red & $F f$ & $V v^{\rho}$ \\
\hline Red Flash & Unknown & Fancy & Red & $F F$ & $V v^{\rho}$ \\
\hline White Christmas & Unknown & Fancy & Green & $F F$ & $\nu^{\rho} V^{\rho}$ \\
\hline
\end{tabular}

Table 2. Segregation ratios for color of the main vein in caladium progeny.

\begin{tabular}{|c|c|c|c|}
\hline \multirow[b]{2}{*}{ Crosses (female $\mathrm{x}$ male) } & \multicolumn{3}{|c|}{ Color of main vein } \\
\hline & $\frac{\text { Red }}{\left(V_{\perp}\right)}$ & $\begin{array}{c}\text { White } \\
\left(V^{N} V^{w} \text { or }\right. \\
\left.V^{N} V^{g}\right)\end{array}$ & $\frac{\text { Green }}{\left(V^{\mathcal{g}} V^{g}\right)}$ \\
\hline Candidum $\times$ Candidum & 0 & 0 & 1 \\
\hline Candidum x Candidum Jr. & 0 & 0 & 1 \\
\hline Candidum Jr. x Fantasy & 1 & 0 & 1 \\
\hline Fantasy x Candidum Jr. & 1 & 0 & 1 \\
\hline White Christmas x Fantasy & 1 & 0 & 1 \\
\hline Red Ruffles x Candidum & 1 & 0 & 1 \\
\hline Red Ruffles x Candidum Jr. & 1 & 0 & 1 \\
\hline Sweetheart x Candidum & 1 & 0 & 1 \\
\hline Sweetheart x Candidum Jr. & 1 & 0 & 1 \\
\hline Candidum Jr. x Sweetheart & 1 & 0 & 1 \\
\hline
\end{tabular}


Table 2. Segregation ratios for color of the main vein in caladium progeny.

\begin{tabular}{|llll|}
\hline \hline Candidum x Red Flash & 1 & 0 & 1 \\
Red Flash x Red Flash & 3 & 0 & 1 \\
Fantasy x Red Flash & 3 & 0 & 1 \\
Moonlight x Moonlight & 0 & 3 & 1 \\
Moonlight x Fantasy & 2 & 1 & 1 \\
Moonlight x Red Flash & 2 & 1 & 1 \\
Sweetheart x Moonlight & 2 & 1 & 1 \\
Aaron x Red Flash & 1 & 1 & 0 \\
Red Flash x Aaron & 1 & 1 & 0 \\
\hline \hline
\end{tabular}




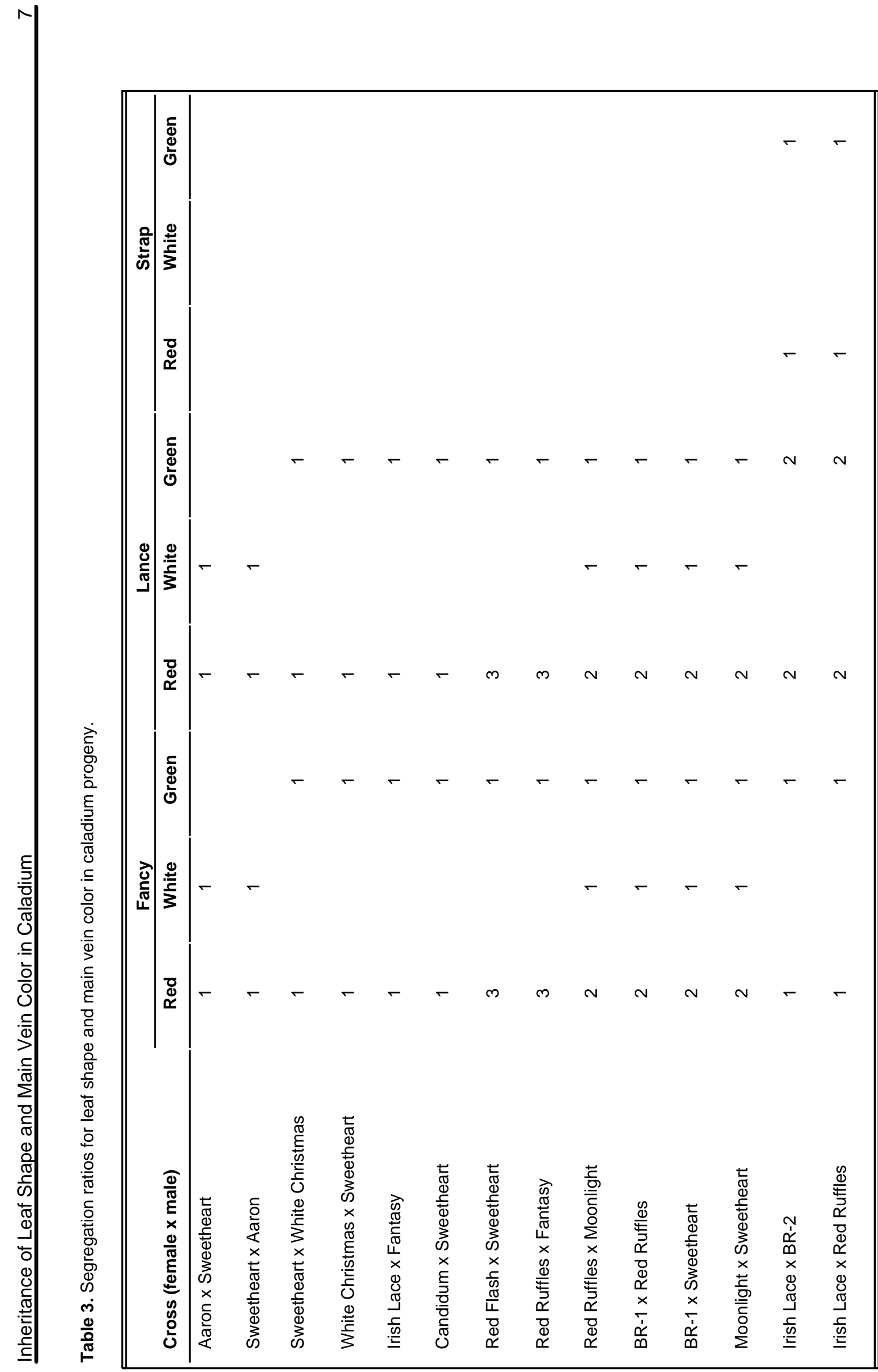

